\title{
Przydatność dla hodowli miejscowych populacji owsa siewnego o wysokim zróżnicowaniu cech fenotypowych
}

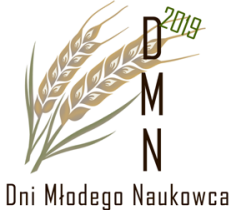

\author{
The importance of local oat populations with a wide variety of phenotypic traits \\ in relation to breeding process
}

Grzegorz Kloc ${ }^{凶}$, Denise F. Dostatny

Instytut Hodowli i Aklimatyzacji Roślin - Państwowy Instytut Badawczy,

Krajowe Centrum Roślinnych Zasobów Genowych, Radzików 05-870, Błonie,

$\triangle$ e-mail: g.kloc@ihar.edu.pl

\begin{abstract}
Wyjazdy kolekcyjne są jednym z ważniejszych źródeł pozyskiwania materiałów w Krajowym Centrum Roślinnych Zasobów Genowych (KCRZG). Wybór Litwy jako obszaru poszukiwań zasobów genowych był związany z historycznymi relacjami z Polską. W latach 2011 - 2013 przeprowadzono trzy ekspedycje, podczas których zebrano 32 obiekty Avena sativa L. wraz z danymi paszportowymi. Zebrane próbki zostały wysiane na $2,5 \mathrm{~m}^{2}$ poletkach Instytutu Hodowli i Aklimatyzacji Roślin (IHAR-PIB) w Radzikowie w latach 2012, 2013, 2014. Na każdym poletku, ręcznie wysiano 600 nasion. Odnotowywano stan wylegania roślin, pojawiające się choroby, wyliczono masę tysiąca ziaren oraz plon. U większości obiektów wiechowanie występowało później niż u odmian wzorcowych. Lokalne obiekty odmian owsa były wyższe od wzorcowych obiektów a mimo to odznaczały się niskim stopniem wylegania. Lokalne odmiany owsa mogą stanowić źródło pojedynczych, unikalnych cech poszukiwanych przy tworzeniu nowych odmian.
\end{abstract}

Słowa kluczowe: owies, ekspedycje, zasoby genowe

Collecting missions are among the most important sources of collecting materials at the National Center for Plant Genetic Resources (KCRZG). The choice of Lithuania as a place to search for genetic resources was associated with historical relations with Poland. In the years 2011 - 2013 three collecting missions took place, collecting 32 accessions of Avena sativa L. with passport data. Collected samples were sown on $2.5 \mathrm{~m} 2$ plots at Radzików IHAR in 2012, 2013, 2014. 600 seeds were manually sown on each plot. During observations, plant lodging andemerging diseases were noted, and thousand grain weight and yield was calculated. For most accessions, panicles appeared later than in reference varieties. Local objects in this category were higher than the reference objects and had a low lodging degree. Local oat can be a source of individual, unique traits for breeding.

Key words: oat, collecting missions, gene resources

\section{Wstęp}

Zbiór miejscowych oraz regionalnych odmian roślin rolniczych jest ważnym elementem $\mathrm{w}$ poszukiwaniu specyficznych cech, takich jak odporność na choroby czy przystosowanie do lokalnych warunków środowiskowych. Mogą one stanowić źródło przydatnych cech w hodowli nowych odmian. Kluczowym elementem globalnego bezpieczeństwa żywnościowego jest różnorodność genetyczna roślin, zapewniana poprzez gromadzenie obiektów podczas wyjazdów kolekcyjnych. Jest ona przydatna zarówno $\mathrm{w}$ procesie hodowlanym, jak i w zachowaniu bioróżnorodności roślin. (Rocha i in. 2017). Wybór obszaru poszukiwań zasobów genowych był związany z historycznymi relacjami Litwy i Polski. Decyzję o organizacji wyprawy na Litwę podjęto, ponieważ tereny te przez dłuższy czas i w dużym stopniu zamieszkiwane były przez Polaków. Nadal widoczne jest tam podobieństwo w sposobie uprawy. W przeszłości miała miejsce duża wymiana, zarówno materiału siewnego, jak i informacji na temat sposobów prowadzenia gospodarstwa. Celem wypraw terenowych na Litwę był zbiór nasion roślin rolniczych do dalszego rozmnożenia oraz ewaluacji, a także ich zdeponowanie w przechowalni długoterminowej KCRZG. Celem pracy jest ukazanie wstępnej ewaluacji zebranych obiektów owsa podczas trzech ekspedycji na Litwę z zamiarem wyboru tych najbardziej przydatnych z przeznaczeniem do dalszych badań.

\section{Metodyka}

Litwa charakteryzuje się klimatem przejściowym. Średnia temperatura w lipcu wynosi $+16,7^{\circ} \mathrm{C}$, w styczniu $-4,1^{\circ} \mathrm{C}$ (https://tradingeconomics.com/lithuania/temperature). Grunty rolne zajmują 47,98\% (https://tradingeconomics.com/ 
lithuania/agricultural-land-percent-of-land-area -wb-data.html). Natomiast w Polsce średnia temperatura w lipcu wynosi $+16,8^{\circ} \mathrm{C}$, w styczniu $-2,7^{\circ} \mathrm{C}$ (https://tradingeconomics.com/poland/temperature), a grunty rolne zajmują $46.93 \%$ powierzchni kraju (https://tradingeconomics.com/poland/agricultural-land-percent-of-land-area-wb-data.html). W latach 2011 - 2013 przeprowadzono trzy ekspedycje, podczas których zapisywano dane paszportowe wraz z cechami użytkowymi zbieranych próbek, a także wskazówkami od gospodarzy dotyczącymi ich uprawy. Zapisywanie dokładnych danych paszportowych jest istotne w przypadku zapoznawania się z wiedzą o tradycyjnych metodach uprawy oraz zmianach w nich wprowadzanych, które mogą wynikać z postępujących zmian klimatu (Bioversity International, 2015). Po powrocie $\mathrm{z}$ ekspedycji wszystkie informacje zostały wprowadzone do bazy danych w KCRZG IHAR-PIB w Radzikowie, a próbki owsa siewnego rozmnożono na poletkach doświadczalnych IHAR-PIB w Radzikowie. Zebrane próbki zostały wysiane na $2,5 \mathrm{~m} 2$ poletkach w latach 2012, 2013, 2014. Na każdym poletku, ręcznie wysiano 600 nasion. Odnotowywano stan wylegania roślin (skala 0-9, 9 oznacza brak wylegania) oraz pojawiające się choroby (septorioza, mączniak oraz rdza koronowa) w dwóch terminach $\mathrm{w}$ czasie sezonu wegetacyjnego. Wyliczono mase tysiąca ziaren (MTZ) oraz plon w gramach (w przeliczeniu na $\mathrm{kg}$ ). W 2012 roku odmianę wzorcową w doświadczeniach stanowiła polska odmiana „Krezus”, a w 2013 i 2014 - „Celer”.

\section{Wyniki i dyskusja}

Podczas trzech ekspedycji zorganizowanych w latach 2011-2013 na terenie Litwy zebrano nasiona 124 obiektów należących do 6 gatunków roślin zbożowych, w tym 32 obiekty owsa siewnego (tab. 1). Duża część zebranych obiektów owsa była uprawiana na paszę, a niektóre pochodziły z mieszanek zbóż. W 2011 roku zebrano 9 prób Avena sativa L., cztery $(138,139$ 144, 168) o przeznaczeniu spożywczym, a pozostałe obiekty o przeznaczeniu na paszę. W 2012 roku zebrano 19 obiektów, 6 pochodziło z mieszanek z jęczmieniem (006, 383, 389, 390, 289, 309); 2 próbki o przeznaczaniu na kiełki (338 oraz 360), a pozostałe 11 na paszę. Natomiast w 2013 roku w rejonie solecznickim zebrano tylko 5 próbek, które pochodziły z mieszanek, najczęściej z jęczmieniem, a także z żytem, grochem oraz peluszką, o przeznaczeniu wyłącznie na paszę.

Wśród obiektów Avena sativa L. obserwowanych w roku 2012 faza wiechowania najwcześniej wystąpiła dla obiektu LITLIT11 139, jednocześnie
Tabela 1

Table 1

Obiekty zebrane podczas trzech wyjazdów kolekcyjnych na terenie Litwy w latach 2011 - 2013

Samples collected during three collecting missions in Lithuania in 2011 - 2013

\begin{tabular}{l|c}
\hline $\begin{array}{l}\text { Zboża } \\
\text { Cereals }\end{array}$ & $\begin{array}{c}\text { Liczba obiektów } \\
\text { Number of samples }\end{array}$ \\
\hline Hordeum vulgare L. & 31 \\
Triticum aestivum L. & 31 \\
Triticum spelta L.W & 1 \\
$\times$ Triticosecale Wittm. ex & 14 \\
A.Camus & \\
Avena sativa L. & 33 \\
Secale cereale L. & 15 \\
\hline Lącznie / Total & $\mathbf{1 2 5}$ \\
\hline
\end{tabular}

był on jednym z najszybciej dojrzewających. Obiekt był najniższy w danym roku, wyleganie nie wystąpiło oraz nie odnotowano występowania chorób. Charakteryzował się on najwyższą masą tysiąca ziaren (MTZ 38,6 g), najwyższą masą ziaren po omłóceniu oraz jednym $\mathrm{z}$ najwyższych plonów $(1,24 \mathrm{~kg} / 2,5 \mathrm{~m} 2,70 \%$ odmiany wzorcowej). Najsłabiej pod względem wielkości plonu $(0,52 \mathrm{~kg} / 2,5 \mathrm{~m} 2)$ mimo braku wylegania i wysokiej odporności na choroby prezentował się obiekt LITLIT11 119, który stanowił zaledwie 30\% plonu odmiany wzorcowej (rys.2 A).

W rozmnożeniu w roku 2013 podczas obserwacji najwyższy plon $(1,58 \mathrm{~kg} / 2,5 \mathrm{~m} 2,87 \%$ odmiany wzorcowej) oraz MTZ (31 g) (rys.2 B) odnotowano dla obiektu LITZAP12 360 jednocześnie przy jego wysokiej odporności na mączniaka prawdziwego oraz rdzę koronową. Wiechowanie tego obiektu wystąpiło pod koniec czerwca. Jest to owies z łuską, uprawiany na ziarno $\mathrm{z}$ przeznaczeniem na kiełki. Najsłabiej prezentował się obiekt LITZAP12 390 , posiadał najniższy plon $(43 \% \mathrm{w}$ stosunku do odmiany wzorcowej), niskie MTZ $(21,7 \mathrm{~g})$ oraz wykazywał się najwyższym porażeniem rdzą koronową (rys. 2). (rys.1 B). Podczas, gdy u odmian wzorcowych porażenie mączniakiem odnotowano w przedziale między 4 a 6 , to w przypadku odmian miejscowych był to przedział między 7 a 9 oraz 8 z 19 obiektów wykazywało się brakiem porażenia przez mączniaka (rys.1 B).

W roku 2014 u większości obiektów zaobserwowano porażenie mączniakiem (rys.1 C) i brak wylegania pomimo, że rośliny były wyższe w porównaniu do roślin wzorcowych. Wiecha obiektu LITCEN13 399 z największym plonem (980 g), (rys.2 C) pojawia się najpóźniej pod koniec 
czerwca. Owies ten pochodzi z mieszanki (wyka, peluszka, owies) uprawianej na paszę dla zwierząt.

Zaobserwowano duże zróżnicowanie cech fenotypowych między badanymi miejscowymi populacjami owsa siewnego. Otwiera to drogę do selekcji korzystnych cech dla hodowli, (Łapiński i in 2013; Kordulasińska i Bulińska-Radomska 2014; Pszczółkowski i Sawicka, 2016). Według Nita (2003), odmiany wykazujące się najlepszymi cechami morfologicznymi czy rolniczymi powinny być wykorzystywane $\mathrm{w}$ procesie hodowlanym do tworzenia genotypów o pożądanych właściwościach (Nita, 2003). Iannucci i inni (2011) dodatkowo podkreślają, że brak silnych sprzężeń między badanymi cechami pozwala na uzyskanie „użytecznych kombinacji” do badań hodowlanych.

\section{Podsumowanie}

Odmiany lokalne Avena sativa L. pozyskane w czasie ekspedycji na terenie Litwy charakteryzowały się dużą zmiennością cech. U większości obiektów wiechowanie występowało później niż u odmian wzorcowych. Lokalne obiekty odmian owsa były wyższe od wzorcowych obiektów, a mimo to odznaczały się niskim stopniem wylegania. Zaobserwowano mniejsze zróżnicowanie pod względem masy tysiąca ziaren (MTZ) w porównaniu z wzorcami mimo tego, że plon odmian lokalnych był ogólnie niższy. Obiekty zebrane w 2012 r. odznaczały się większą odpornością na mączniaka

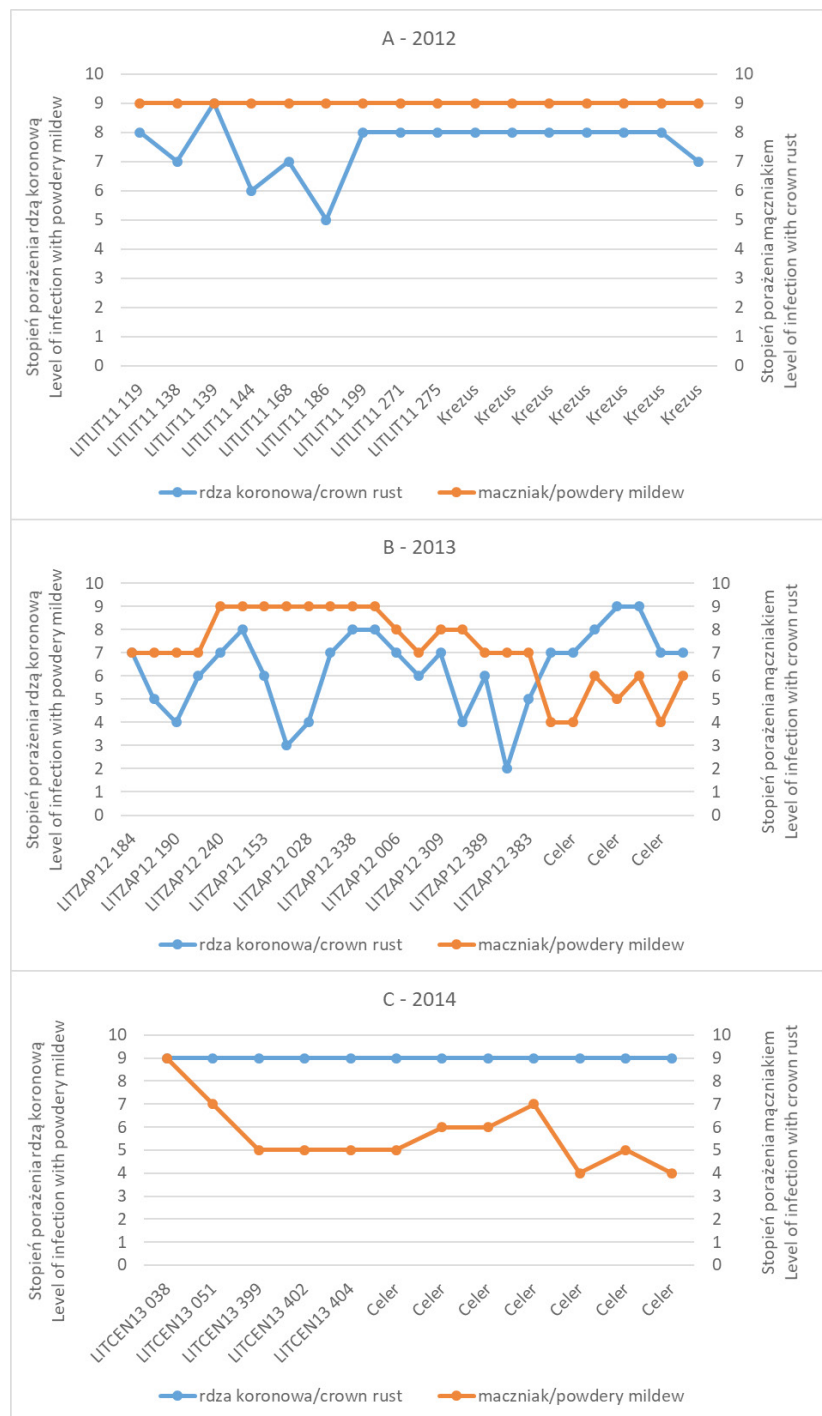

Rys. 1. Stopień porażenia mączniakiem prawdziwym oraz rdzą koronową obieków Avena sativa L. (2012-2014)

Fig. 1. Susceptibility of Avena sativa L. for powdery mildew and crown rust (2012-2014).
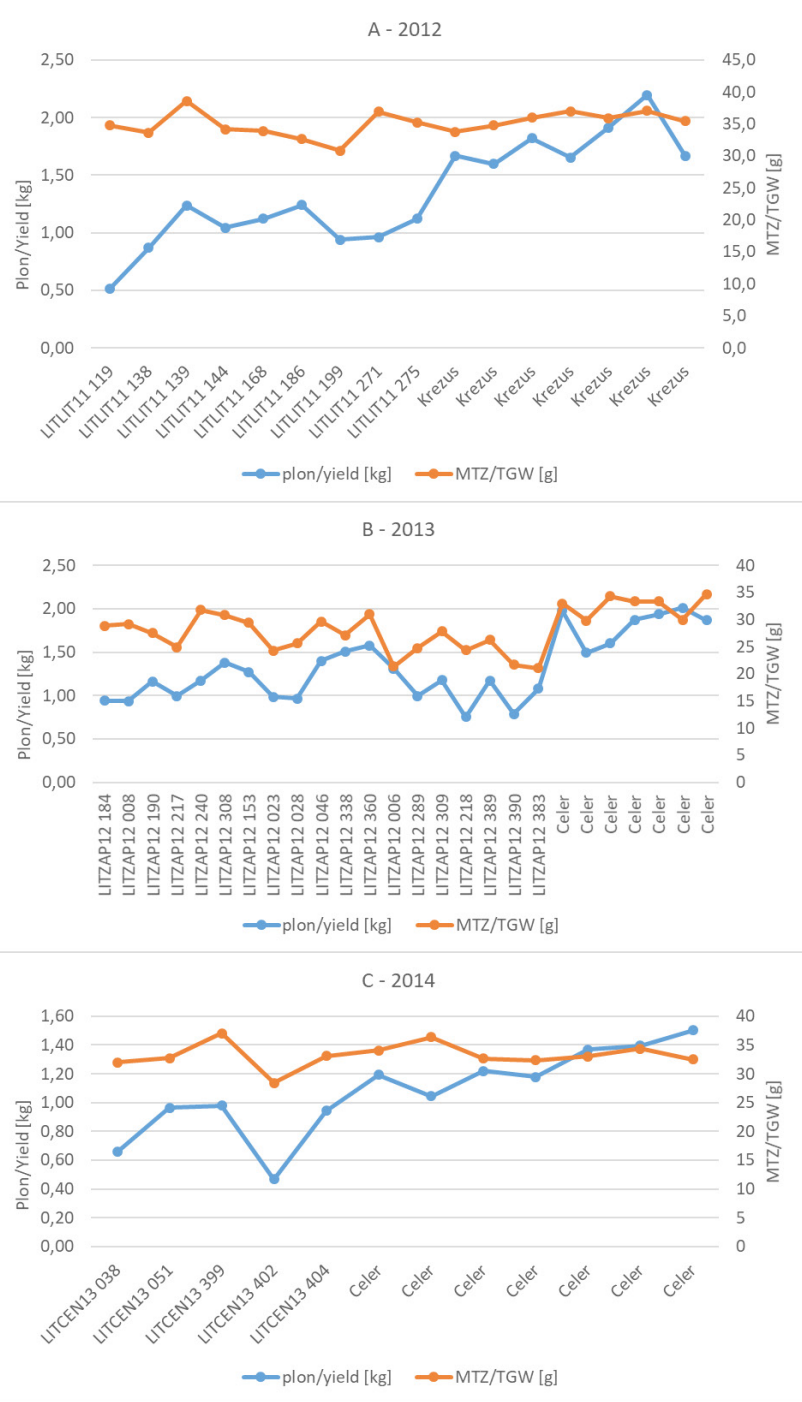

Rys. 2. Wysokość plonu oraz masa tysiąca ziaren obiektów Avena sativa L. (2012-2014).

Fig. 2. Yield level ond thousand grain weight for Avena sativa L. (2012-2014). 
niż odmiany wzorcowe. Lokalne odmiany zebrane w 2013 r. w regionie solecznickim, gdzie nie ma tradycji uprawiania owsa były użytkowane tylko na paszę, dlatego odznaczały się niskimi parametrami plonu. Lokalne odmiany owsa mogą stanowić źródło pojedynczych, unikalnych cech, poszukiwanych do stworzenia nowych odmian.

\section{Literatura}

Bioversity International. (2015). The history of Bioversity International collecting missions.: http://www.bioversityinternational.org/e-library/databases/collectingmissions/history/(dostęp: październik 2019).

Iannucci, A., Codianni, P., Cattiveli, L., (2011). Evaluation of Genotype Diversity in Oat Germplasm and Definition of Ideotypes Adapted to the Mediterranean Environment. International Journal of Agronomy: 1-8.

Kordulasińska, I., Bulińska-Radomska, Z., (2014). Ocena cech morfologicznych, użytkowych i składu chemicznego obiektów owsa zgromadzonych w Krajowym Centrum Roślinnych Zasobów Genowych w Radzikowie. Polish Journal of Agronomy, 16: 3-12.
Łapiński, B., Nita, Z., Szołkowska, A., Wieczorek, P., (2013). Mieszaniec owsa uprawnego z dzikim gatunkiem Avena macrostachya jako nowe źródło zmienności do poprawy jakości plonu owsa nagoziarnistego. Biuletyn IHAR, 270: $43-54$.

Nita, Z. T., (2003). Współczesne osiągnięcia i perspektywy hodowli owsa w Polsce. Biuletyn IHAR, 229: 13-20.

Pszczółkowski, P., Sawicka, B., (2016). Zmienność form i odmian owsa w Polsce. Polish Journal of Agronomy 27: 106-117.

Rocha, F., Gaspar, C., Barata, A. M., (2017). The legacy of collecting missions to the valorisation of agro-biodiversity. Agriculture \& Foresty, vol 63, issue 2: 25-38.

Trading Economics. https://tradingeconomics.com/poland/ agricultural-land-percent-of-land-area-wb-data.html.

Trading Economics. https://tradingeconomics.com/poland/ temperature.

Trading Economics. https://tradingeconomics.com/lithuania/ agricultural-land-percent-of-land-area-wb-data.html.

Trading Economics. https://tradingeconomics.com/lithuania/ temperature (dostęp: październik 2019).

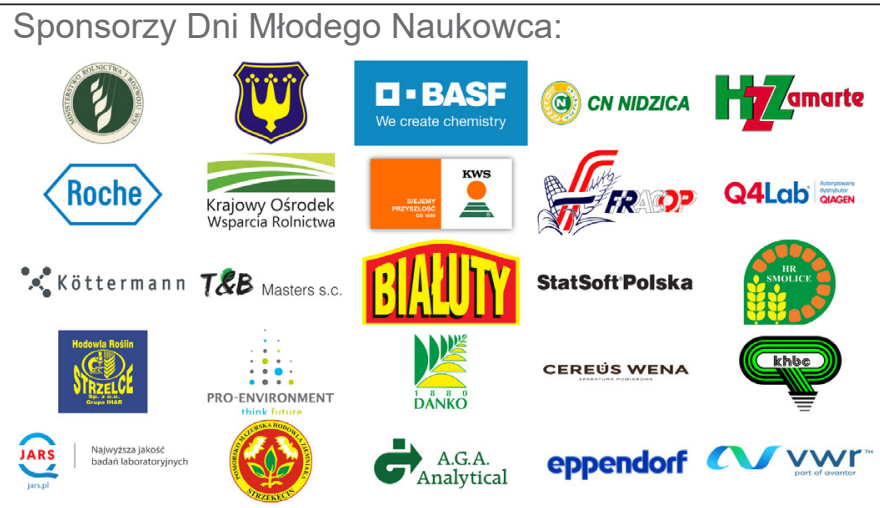

